\title{
Formation of Human Capital in the Digital Economy*,**
}

\author{
Leonid HR. Melnyki, Oleksandr M. MatsenKo ${ }^{i i}$, Vladyslav S. Pivenii, \\ OleKSANDR M. DERYKOLENKo ${ }^{i v}$, MaKSYM V. KYrYLENKO ${ }^{v}$
}

The article studies the role and various manifestations of human capital in the functioning and development of the digital economy. The key context of the research is the phenomenon of reproduction of the components of human capital, including the processes of production and consumption. As an important prerequisite for reproduction, the phenomenon of streamlining the three basic origins of functioning of economic systems is analyzed: material, informational and synergetic. The relationship and interaction of these origins play an important role in the formation of various types of capital, including human capital. The article reveals the content and directions of investing in the main components of the reproductive cycle of the economic system: demand, property relations, performers, governing bodies, infrastructure, and natural factors. The article focuses on the analysis of the trialectic foundations of the reproduction of human capital through the formation and interaction of the essential origins of man: biological, social, and labor. The man-consumer of the digital economy is fundamentally different from the human-consumer of previous eras. The main thing is that the vast majority of personal needs become an end in itself, rather than a means of obtaining material benefits in the future. Man-producer will increasingly move from the impact on material objects of labor (change of shapes, sizes, properties) to the impact on information (development of creative industries, the selection of useful information from large data sets). Based on the analysis of the substantive basis of the three industrial revolutions (third, fourth, and fifth), transformational changes are predicted, which should take place during the phase of transition to a new socio-economic formation. The main ones are sustainization of human consciousness, digitalization, and networkization of competencies; formation of the ability to live in the conditions of Internet of Things; sociologization of development, etc.

Keywords: human capital, economic system, process, digital economy, industrial revolutions.

${ }^{i}$ Leonid Hr. Melnyk, Dr. (Economics), Professor, Professor of Department of Economics, Entrepreneurship and Business-Administration, Director of Research Institute for Development Economics (IDE) at Sumy State University;

ii Oleksandr M. Matsenko, C.Sc. (Economics), Associate Professor, Associate Professor of the Department of Economics, Entrepreneurship and Business Administration, Sumy State University;

${ }^{i i i}$ Vladyslav S. Piven, Student, Oleg Balatskyi Academic and Research Institute of Finance, Economics and Management, Sumy State University;

${ }^{\text {iv }}$ Oleksandr M. Derykolenko, Dr. (Economics), Associate Professor of the Department of Economics, Entrepreneurship and Business Administration, Sumy State University;

${ }^{v}$ Maksym V. Kyrylenko, Student, Oleg Balatskyi Academic and Research Institute of Finance, Economics and Management, Sumy State University.

* This research was funded by a grant from the state budget of the Ukraine "Fundamentals of the phase transition to the additive economy: from disruptive technologies to institutional sociologization of decisions" (No. 0121U109557)

${ }^{* *}$ The publication contains the results of research of European Commission grants "Jean Monnet Chair in EU Economic Policies and Civil Society" (619878-EPP-1-2020-1-UA-EPPJMO-CHAIR) and EU legislative, economic and social transition to sustainable society within Industry 4.0 and 5.0 (619997-EPP-1-2020-1-UA-EPPJMO-CHAIR).

(C) L. Hr. Melnyk, O. M. Matsenko, V. S. Piven, O. M. Derykolenko, M. V. Kyrylenko, 2020.

https://doi.org/10.21272/mer.2020.90.02 
Introduction. The concept of human capital became widespread in economics in the second half of the $\mathrm{XX}^{\text {th }}$ century. However, it was quite harmoniously included in the definitions of capital, which were given by the classics of economic theory: A. Smit (Smit, 1993), K. Marks (Marks, 1983), A. Marshall (Marshall, 1993), J.- B. Say (Say, 2000), J. Clark (Clark, 2000), J. Schumpeter (Schumpeter, 2011), and others.

Among those who began to use actively the term «human capital» in their works and to develop the related theoretical foundations, we should first mention G. Becker (Becker, 1994); T. Schultz (Schultz, 1961); J. Mincer (Mincer, 1958); L. Thurow (Thurow, 1970). The main attention in these works was paid to the issues of investing in human capital.

In the 21 st century, the importance of human capital in economic systems has increased significantly. It is now becoming increasingly clear that the success of the economic system, from individual enterprises to national economies, is determined not by the availability of natural resources or even financial assets, but by the quality of human capital (Melnyk et al., 2019; Tarkhov et al., 2011, 2012, 2013; Matsenko et al., 2012, 2018).

Today, as humanity enters a phase of the transition to a new socio-economic formation, which can be called a «digital economy», the issues of filling the content of structural and qualitative transformations of human capital during the industrial revolutions (Industries 3.0, $4.0,5.0$ ), which increasingly begin to define the contours of economic systems, become more urgent. These questions are considered in the article.

\section{Fundamentals of capital formation}

Man has always been a key factor in the functioning and development of social, and, since the formation of the first agrocoenosis, biosphere systems. The leading role of man is due to the two groups of functions performed by man. First, as a consumer, a person forms the goals of the functioning and development of socio-economic systems and therefore sets the direction and pace of their movement and transformational change. Secondly, as a producer, man determines the nature of productive forces, including the means of meeting these needs (technological basis, types of relations with nature, the specifics of human activities, lifestyle, etc.).

The multifaceted nature of a social life causes a significant difference in views on the specifics of its components. A feature of economic systems is the reproducible nature of their components. Reproduction itself is the basis for determining one of the main economic categories, namely capital. (Simplified scheme of reproduction of the economic cycle is shown in Fig. 1).

In a broad context, capital is the aggregate means, resources, which are used in the economic process (business) (Smit, 1993; Marshall, 1993; Vechkanov et al., 2002), resources for the production of goods and services (Schumpeter, 2011; Rayzberg, 2010; Economic, 1999) or production factors (Say, 2000; Clark, 2000; Dictionary, 2003).

From a physical point of view, any economic system is an open stationary system that carries out material and information metabolism, maintaining the state of its homeostasis. As it is known, for a physical system, energy is defined as a general quantitative measure of various forms of motion, change, and conversion of matter, or the interaction of material objects inside and outside the system. The system loses energy by carrying out metabolic processes. The system compensates for the consumed energy by importing free energy from the external environment through the involvement of energy-intensive substances (energy resources) in the system. 
ENTRANCE

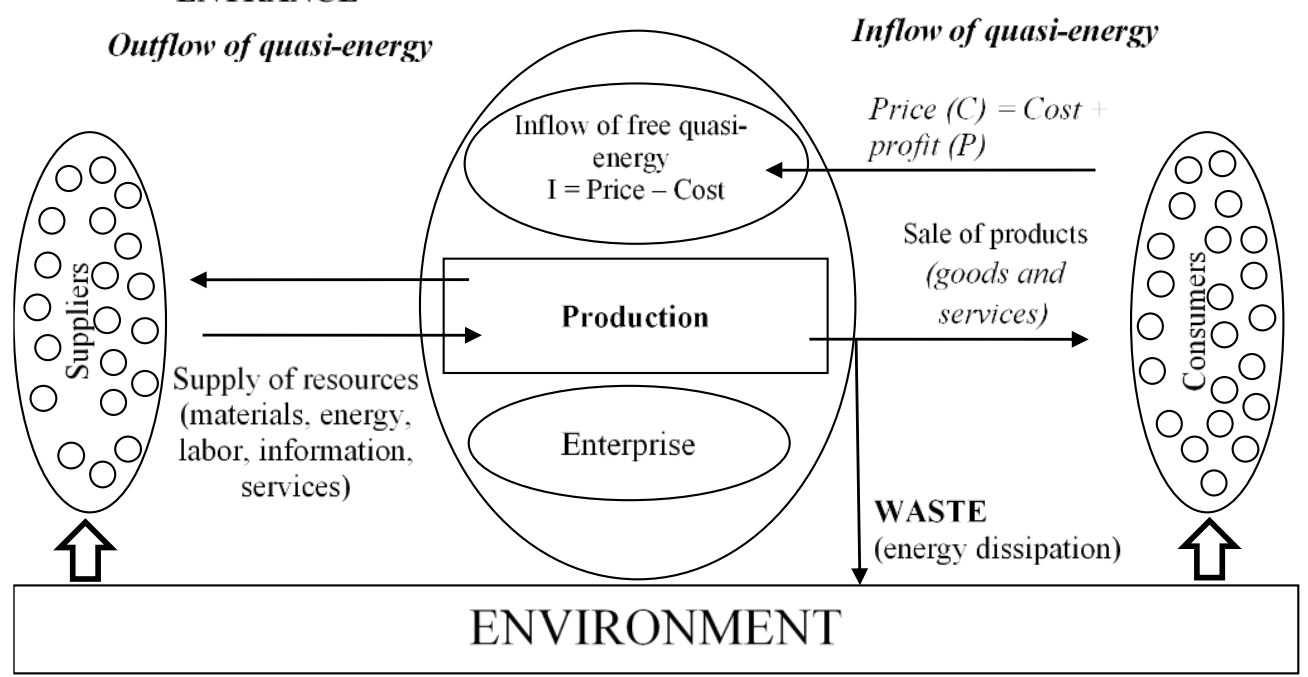

Figure 1. Simplified scheme of the reproductive economic cycle

For the economic system, the conditional «energy resources» or quasi-energy resources are material, informational and material-informational assets that determine the ability of the system to perform work, including of physical and mental nature. In this interpretation, quasi-energy resources include any type of capital, including natural and human capital, as well as tangible and intangible assets, money, and their analogs (bonds, other securities, etc.).

For the functioning and development of economic systems, it is necessary to reproduce constantly the conditions of their order, which have trialectic nature, as realized through the interaction of three groups of factors: material, informational and synergetic, the conditional scheme of which is shown in Fig. 2. It is quite reasonable, as we see, that capital is called the material basis of market relations (Popular, 2001). And according to one version, in addition to the feature of «total resources of the economic process» contained in the above definitions, the concept of capital also includes a set of economic relations inherent in the capitalist way of production (Marks, 1983; Vechkanov et al., 2002).

Each of the following in Fig. 2 groups of factors in their way are important for the functioning and development of economic systems. We can even say that these groups of factors, such as the Hypostases of the Christian Trinity, are equal in different ways. In particular, any natural or social system can be destroyed by negatively affecting each of the groups of factors.

For example, the work of a computer can be blocked: a) by destroying some material part; b) by violating its software, namely information software; c) by disconnecting from the Internet or at least from the electrical network (breaking the synergistic connection with the external environment).

A similar situation can be observed on the example of ecosystem destruction through: a) destruction of biological species (material destruction); b) their diseases (information destruction); c) blocking of communications (connections) in the system (synergetic destruction). 


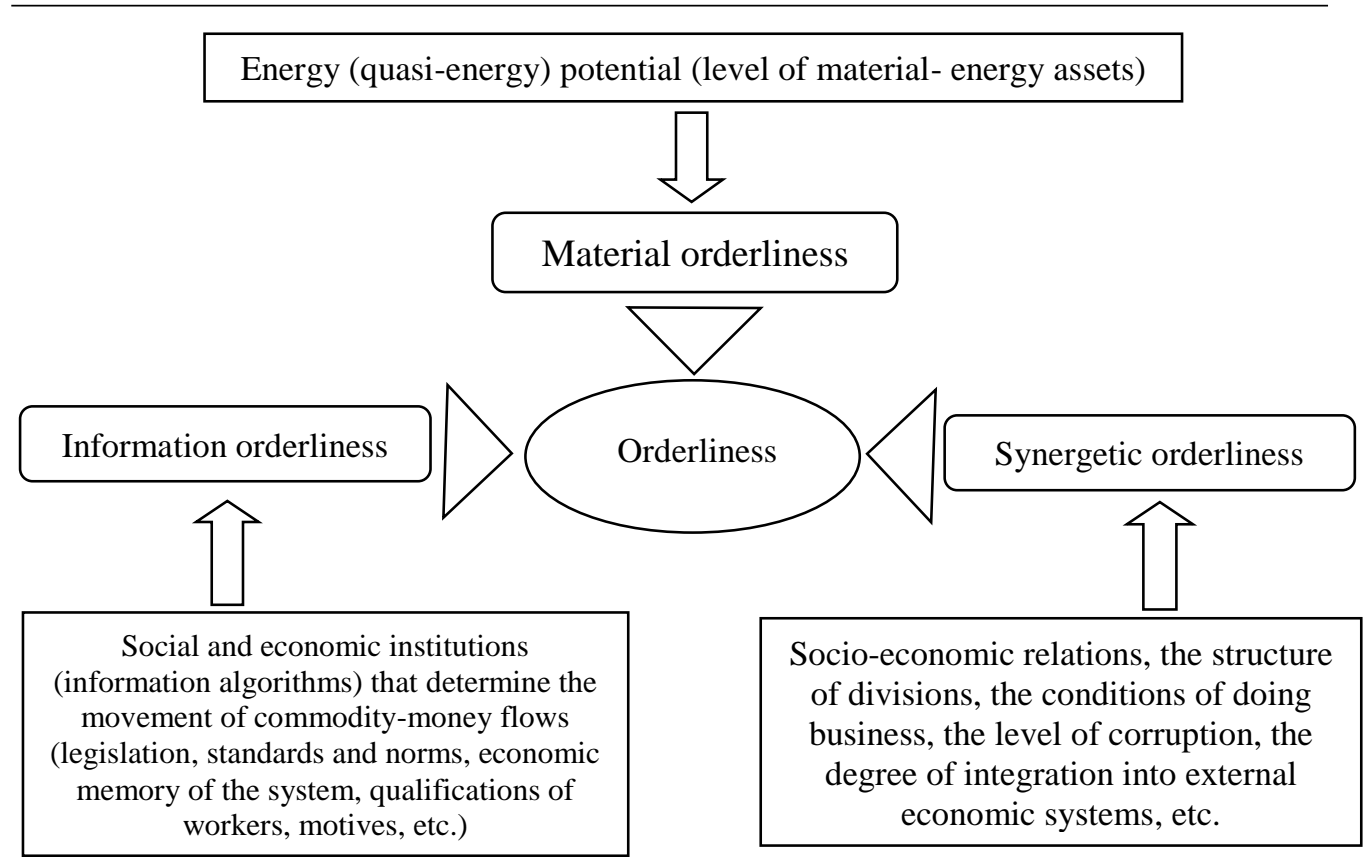

Figure 2. The scheme of conditions reproduction of the orderliness of economic systems functioning and development

Accordingly, the improvement of the functioning of the system is due to the opposite processes of reproduction of each of the groups of factors. The peculiarity of different types of capital is that their reproduction is carried out through investment, namely purposeful spending of various assets or the application of human labor.

Many definitions of capital determine the ability to bring income to its owner as one of its key features. Note that, in our opinion, this phenomenon is indirectly expressed only by the condition of providing a means of reproduction and development of capital (in particular, through self-sufficiency). Return on capital is not always a priority for all its owners.

It is unlikely that for such obsessed with achieving high goals as E. Musk, earning and increasing wealth is the primary goal. Rather, perhaps the opposite: money serves only as a means to achieve purely technical and social goals.

An example can be given from the history of the whole community - the Nepluev Brotherhood. There, the primary goal was the personal development of man (as they would now say «human capital»). Progressive technical development and economic success were also considered important goals in the Brotherhood. But it was considered only as a means of ensuring social development (Melnyk, 2018).

In our opinion, such a view of the role of capital will come to the forefront as we move towards the information society. This is exactly the idea expressed by K. Boulding in the article «From the cowboy economy to the spacemen economy» (Boulding, 1966). 
Leonid Hr. Melnyk, Oleksandr M. Matsenko, Vladyslav S. Piven,

Oleksandr M. Derykolenko, Maksym V. Kyrylenko. Formation of Human Capital in the Digital Economy

\section{Human capital as the driving force of the economic system}

Man acts as a leading resource (asset) used in all phases of economic systems and, therefore, quite rightly corresponds to the key feature of capital, the definition of which we have given above. Moreover, man is the driving force behind the processes of reproduction of the components of the economic system in the broadest sense of the term. Let's name the specified components.

Demand for enterprise products; it is reproduced through the consistent formation of: needs, interests, financial capacity of consumers to purchase certain types of products. Investment in demand can be carried out through education and self-education of consumers, horizontal dissemination of information between them, through the media, through measures (policies) of state or local administrations (especially for socially important or environmentally friendly products), advertising activities of producers. Each of these activities requires spending money, tangible assets, labor, time. Consumers in all these processes act as subjects of the economic process, forming the purposes (directions) of the manufacture of products, and at the same time are objects of influence of other subjects of the economic process (for example, manufacturers).

Property relations; they are sold by the owners of production assets, which mobilize a critical mass of capital (quasi-energy) to initiate the economic process, and then to adjust the necessary reproduction processes. Investments are made through education and self-education of potential owners, corporatization, lending, and other types of fundraising.

Performers; they carry out the implementation of production processes through the acquisition (at the expense of owners) and the creation of material and information assets, production processes, personnel management, product sales, the supply of resources, the impact on the environment. Investment is carried out through the creation of production assets (through equity, share capital, and borrowed capital), education and self-education of performers, their education and training (formation of beliefs, worldview, knowledge, skills, responsibilities, habits, ability to work in a team, physical and psychological traits).

A higher level of administration and institutions; they are carried out by the governing state and local bodies that provide the institutional conditions in which economic entities operate. It is reproduced at the expense of tax and other revenues (investments) through the formation of appropriate institutions and the necessary measures.

Infrastructure support. It is reproduced at the expense of the state, joint-stock, and private investments to create the necessary conditions for the management of economic systems, in particular, through the objects of communication, educational, health, information, legal, cultural, and other activities.

Natural factors; provide the reproduction of natural resources and components of the natural environment. Sources of investment are funds and activities of the state budget, economic entities, individuals, various funds, and payments.

We emphasize once again that the directions and efficiency of the processes of reproduction of these components fully depend on the qualitative properties of human capital.

K. Marks considered the ability to self-growth to be an important property of capital (according to Marks, capital is a self-growing value). In this case, Marks formulated the necessary condition for such self-growth. A means of labor can exhibit similar properties (bring the owner more value than his own) only when its owner directly or indirectly enters into economic relations with the owner of labor (Marks, 1983). In other words, physical capital must unite with human capital. Only human capital is the driving force of economic processes that activate other components of capital at any stage of its reproduction and rotation. 


\section{Trialectics of reproduction of human capital}

Man as a key factor in the economic system. The main driving force of any socioeconomic system is the activities of people. Man of the economic system performs key functions in the economic system:

- designer (means of production, construction materials, technologies, energy supply systems, consumer goods, human habitat, communications, etc.)

- manufacturer (all of the above);

- organizer (processes of design, production, and consumption of products);

- communicator (the subject that determines the implementation of relations in society);

- consumer (material and information benefits).

It is impossible to understand the content of the development of economic systems without realizing the nature of the essential origins of man, which form the contours of human capital.

Each person is a single system formed by a triad of its essential origins: «bio», «socio», «labor». «Bio» is formed by the material nature of man and is realized through the physiological processes of metabolism occurring in the body. «Socio» is an intangible informational origin that realizes the personal essence. «Labor» operates based on a person's ability to perform work through the integration of human strength traits «bio» and personal characteristics of a person «socio». The difference in the essential origins of man leads to the formation of three different groups of needs, which differ significantly from each other, and in many respects are even contradictory.

Since the formation of society and the emergence of personal origins in man there is the formation of two interconnected systemic entities.

The man continues to be one of the representatives of the animal world, with its inherent metabolism, thermoregulation, movements. In other words, it remains an organism that constantly needs to maintain physiological functions to survive.

On the other hand, a person arises and begins to develop a personal essence, namely a certain intangible, purely informational phantom, which consumes only information. It is likely that this human essence is meant when talking about the «soul» of man. A person's personality can be formed only in society, in interaction with other similar individuals. Thus, the personal essence of man can still be called a social person, or «socio».

The necessary system of conditions of the external environment and the internal nature of man, which ensures the sustainable existence of man as a species, should be considered an ecological factor in human life. Creating the necessary conditions, nature performs its physiological functions in relation to man, ensuring the harmony of the human body with the natural environment. Gradually, man has learned, within certain limits, to artificially create the conditions of his existence, conditioning them to his needs. To do this, a person puts between himself and nature a man-made environment, which is created just by the economy. In it, a man actually exists, consuming no less man-made products (food, drinking water, and consumer goods, including services).

Man himself as a biological being has changed little compared to his ancestors. The limit of human viability still lies in the narrow intervals of environmental conditions, which correspond to the homeostasis of the human body. To analyze the preconditions for the reproduction of human capital, it is advisable to consider the needs of these three human beings.

Man-«bio» needs. In general, the physiological needs of man can be combined into several groups:

- space for existence;

- physicochemical and biological properties of the environment, including space factors; 
- air for breathing;

- food and drinking water resources;

- opportunities for physical activity;

- information, including the presence of positive and negative emotions.

Personal needs of the man. The formation of the foundations of the information society, to which humanity is approaching, requires a deep understanding of the nature of the information person, namely the personal human. After all, in the future information society, it is the personal human who will have to play a major role in the economic system, where the personal («socio»), namely the information essence of man will be the main designer, producer, and consumer of goods and services. The latter for this reason will also be most informative.

It is likely that in the very first approximation, a human's personal needs (namely, those that ultimately form a man-«socio») can be conditionally grouped into the following groups:

- ensuring psychological and social well-being, mental health (development of a sense of optimism, stability, the joy of life, own social necessity);

- the possibility of informational knowledge of the world (including the implementation of cognitive instincts);

- opportunity for creative development (development of creative abilities, a satisfaction of aesthetic needs, development of a sense of beauty and harmony);

- the impulse of creativity (source of inspiration);

- conditions of moral education and improvement; this is what forms the relationship between the needs for themselves and the needs of other people (a sense of patriotism, a tendency to self-sacrifice and self-restraint, a sense of duty, the ability to empathize, etc.).

Man-«labour» needs. Regarding the economic system, man acts in two roles: producer and consumer.

As a consumer, man is the bearer of the needs of the triad of subsystems («bio-labor-socio»), which exists in itself.

The needs of the people are a necessary component of the economic system. For its continuous functioning, it is necessary that the needs of people are constantly reproduced.

The human needs of «labor» as a producer are determined by three main groups of factors:

- resource needs (material, energy, utilization; the latter is limited by the availability of sufficient assimilation «containers» for waste);

- conditions for the reproduction of physiological conditions of man as a labor resource;

- conditions for the reproduction of personal qualities of man as a labor resource.

As we see, the second and third groups of factors determine the needs of man- «labor» the needs of man-«bio» and man-«socio». Looking ahead, this creates a basis for linking a person's physiological and personal needs with economic assessments.

Comparative analysis of the needs of different essential origins of man. Of course, the mentioned division of human beings into «bio», «labor», «socio» is largely conditional. After all, this triad of entities is forced to exist in a single body, sometimes it is difficult to identify the characteristics of each of these entities. With his mind and will, man strives to ensure that the goals of each of the parts of his essential triad coincide or are close to it. In this case, we can assume that there is a harmony of different origins in a person, and he experiences emotional comfort.

Such an analysis is extremely important for the formation of ideas about the role of man in the economic system. A person can act in several interrelated roles, among the most important of which can be called such ones, as designer, manufacturer, and consumer. 
Л. Г. Мельник, О. М. Маценко, В. С. Півень, О. М. Дериколенко,

М. В. Кириленко. Формування людського капіталу в цифровій економіці

Table 1

Comparative scheme of behavioral attitudes-aspirations of «man-labor» and «man-socio»

\begin{tabular}{|c|c|}
\hline Man-«labor» & Man-«Socio» \\
\hline To the end & To the infinite (in the final) \\
\hline To discretion & To integrity \\
\hline Before the analysis & Before synthesis \\
\hline To simplification & To complication \\
\hline To standardization (unification) & To originality (uniqueness) \\
\hline $\begin{array}{c}\text { To the usefulness of individual } \\
\text { components of nature }\end{array}$ & To the value of integral natural \\
systems
\end{tabular}

The evolution of human capital in the transition to the information society. The informational needs of a person «socio» are designed to transform the entire system of values, forming a kind of public order. Its main purpose - to meet the demands, which are necessary for the development of personal qualities. The physiological needs of man-«bio» (needs for food, water, living conditions, etc.) and the technocratic interests of man-«labor» (the pursuit of profit, career growth, prestige, etc.) are replaced by human needs «socio» (physical improvement, intellectual development, the realization of creative abilities, acquisition of knowledge, rest and pleasure).

Man-consumer. The digital economy is fundamentally different from the human consumer of previous eras. The main thing is that the vast majority of personal needs become an aim itself, rather than a means of obtaining material benefits in the future. By the way, the latter gradually turn from primary goals into a means of obtaining informational benefits. Just as today the car is transformed from a means of traveling out of town for growing and harvesting into a means of traveling to the forest or the sea for rest and reproduction of mental forces.

Man-producer will increasingly move from the impact on material objects of labor (change of shapes, sizes, properties) to the impact on the information. Even in the case of the manufacture of material products, the task of the human producer will increasingly shift from the transformation of material substance (this function will be transferred to machines) to the formation of information programs, combining and interacting in space and time of material and information production assets.

Man-designer designs the contours of the environment where a person will live and work, as well as the products that he will consume. We can likely expect two key transformations in the activity of the human designer:

- sphere of consumption: the transition from the design of individual goods and services to the formation of vital complexes (creating conditions for the comfortable existence of man-«bio», the maximum development of man-«socio» and the creative career of man«labor»);

- sphere of production: the transition from the creation of objects of labor alien to nature (in their composition and properties) and «broken» production cycles to the formation of acceptable to natural objects of labor, the production, and use of which is organized in closed cycles. 
The described directions of expected changes, of course, very schematically characterize only some separate features of the difficult multifaceted phenomenon under the conditional name «transition to the digital economy».

\section{The formation of the digital economy and the transit of reproduction of human capital}

Any revolution brings radical changes to society. The Third, Fourth, and Fifth Industrial Revolutions, which happen now, promise to be the basis of a phase transition that changes all spheres of human existence. civilizations, including the means of production, economic relations, lifestyle, basic needs, and occupations, as well as many other attributes of life. Many publications (Agamirzyan, 2013; Rifkin, 2013; Rifkin, 2015; Schwab et al., 2018; Schwab, 2017; Rossi, 2018) consider certain aspects of transformation processes during the Third and Fourth industrial revolutions.

Speaking of the transition to a new socio-economic formation (it is called differently in different sources: digital, additive, sustain, «green», etc. - depending on the key feature underlying the analysis), it should be understood that for humanity it is necessary to prepare for an endless change of basic production origins and social institutions in the next decades. This means that in constant development and transformational shifts human capital should exist, which ensures not only the functioning of ecological systems but also their modification during these industrial revolutions.

It should be noted the close relationship between the emergence and implementation of industrial revolutions, their logical sequence, and causation.

The industry has donated: electricity, engineering, standards, production lines, vending machines, radio and television, new substances, chemical fertilizers, cars and airplanes, computers, copiers and much more. And most importantly, it has brought almost complete literacy population and information goods that satisfy the personal essence of man: literature, cinema, television, sports shows, tourism, etc.

However, it turned out that this comprehensive industrial idyll has one very serious flaw. The industry tends to destroy or pollute the nature around it, trying to subdue it to their interests. The miracle machine turned out to be unusually voracious. For two and a half hundred years after its invention, people are worried about how to feed the insatiable mouth of the machine with coal, oil, and gas. The subsoil is destroyed, landscapes are distorted, ecosystems are disturbed.

With the growth of human education, it became increasingly clear that Nature is a complex system of self-regulation of mass-energy-information-exchange processes, where there are many patterns and limitations. One such restriction has already given people the red light to produce any additional energy other than that which the Earth receives from outer space (particularly from the Sun). Otherwise, it threatens to overheat the planet and unbalance its energy system, and critically disrupt the climate.

Energy dimension. The solution of the ecological and energy problem within the framework of thermal energy has begun to be realized through the use of alternative energy sources that do not add heat to the planet (as traditional energy does due to energy combustion and heat formation due to waste from these processes). Alternative energy sources only redistribute the energy that the planet receives from space. These are, first of all, different solar panels, as well as those generators that use different types of movements or differences in physical potentials (wind, waves, tides, heat pumps, etc.).

Resource dimension creates another problem that is designed to be solved by the Third Industrial Revolution. The fact is that man digs out of the depths of nature so much matter that 
its ecosystems do not have time to restore their landscapes. Man makes good use of no more than $5 \%$ of the extracted material resources. The rest (over 95\%!) return to Nature but in a much more toxic and dangerous form.

Traditionally, people used the so-called subtractive (from the English «subtract») method. It was based on cutting off all the excess during the production process. Thus, at all its stages the same 90$95 \%$ of extracted raw materials remain superfluous. This leaves behind monuments to inefficient production and waste in the form of heaps, landfills, piles of waste, and simple garbage.

The 3D printer works completely differently. Drop by drop, he creates future consumer products, leaving almost no waste. And that's not all! If there are similar 3D printers in different parts of the world, it will be unnecessary to transport manufactured goods over long distances. It will be enough just to transfer their information images from the manufacturer. And the potential consumer can easily «print» them on their 3D printer.

When the contours of the «green» economies loomed on the horizon, another serious problem began to emerge.

The fact is that the new economy can only be a network, where billions of different production units (machines, things, enterprises) will work in a single system. And with such its construction, it will be so informationally complex that a person will no longer be able to control it in real-time. There is only one way out. This system should operate automatically.

The Fourth industrial revolution. Information construction of technical systems on Earth has reached great complexity. Only the most technical systems, armed with the appropriate super-means of information processing, capable of operating at super-speed, can cope with such super-complexity.

Of course, one speed, even a «super» one, clearly did not work. Artificial intelligence is already needed. Because what does «information processing» mean? This is, first of all, its analysis and decision-making and answers to questions, such as: «What to do?» or «When is it better to do something?» or: «Which option is better to choose?» and more.

Revolutionary changes took place, which started the Fourth Industrial Revolution (also called Industry 4.0). First, machines began to evolve into cyber-physical systems. They «see» and «hear» around the senses - sensors, and «think» with a computer «brain».

The second event was that all these cyber-physical systems merged into a single technical civilization. This phenomenon is called the Internet of Things. Communicating with each other through the Internet, things were able to make their own decisions, produce goods, serve the person, adapting to our desires and preferences.

The Fifth industrial revolution. Implementation of Industry 4.0 in the new volume of raises another problem, which is to be solved by the Fifth Industrial Revolution. The fact is that cyberphysical system that does not require the participation of the human factor displace man from the production space. This poses significant threats to the personal development of mankind. After all, without the need to solve serious problems of economic development, humanity is doomed to consumer degradation. It is the search for the place of man in the economic system of the cyber-physical age that is aimed at the development of man.

According to the authors of the concept of human beings, a man really must abandon the processes of production, from which he is already being displaced by cyber-physical systems and the Internet of Things. They will perform all routine, standard, monotonous and uninteresting work. But the person who will leave production will be a man-«labor», who is accustomed to performing standard operations that produce standardized products for consumers with standard needs and requests. 
In place of the man-«labor» in the production must come a completely different person - a man-personality. Instead of making products, it will create information images that will easily materialize additive technological systems with the help of 3D printers. That's similar to how 2D printers now print everything we have invented on the displays. Moreover, the final product will materialize at its destination, namely at the consumer's address. And what is important this product will be personalized, namely made according to individual wishes and preferences of consumers.

This is extremely important. After all, the main consumer will also be a person. And the personal development of mankind is possible only where people differ from each other, and this difference will increase.

And the production itself will not be like what we are used to. There will be no fences, no passages, no passes, no rattling equipment. The latter may remain in some form. However, it will not irritate a person there, because it will work independently under the control of Internet of Things.

Transit of human capital. In a concise article, we do not have the opportunity to set ourselves a large-scale task of a systematic analysis of the possible dynamics of the human capital content during the phase of transition. Let us identify only the key areas of the necessary transformational changes in human competencies, which can ensure adequate functional activity of human capital in the context of these three industrial revolutions. The main directions of human transformation, which are dictated by their specifics, include:

- sustainization (including greening) of human consciousness; the ability to «think globally, act locally» is especially important in order to implement specific activities taking into account the possible global and long-term consequences;

- restructuring of professional knowledge and skills for the production and operation of alternative technologies («green» energy and additive production methods);

- digitalization of competencies; involves mastering the skills of digital transmission of information, control over the relevant production tools and remote communications;

- mastering the competencies of the owner of alternative technologies and the subject of solidarity economy;

- networking of competencies; involves the formation of the necessary knowledge and skills to carry out the necessary professional activities through the Internet or its use as a working tool;

- formation of skills to live and act in the conditions of total introduction of means of the Internet of Things;

- sociologization of development; transition to priority development of the man origins in the conditions of full maintenance of material well-being and automation of production;

- formation of synergetic connection with cyber-physical systems and artificial intelligence.

Taking into account the leading nature of human capital in the development of socioeconomic systems, these transformational trends can be seen as crucial steps in the transition of mankind to the «digital» economy.

Conclusions. Human capital is the driving force of both the reproduction of various forms of capital and the functioning of economic systems in general. With careful analysis, we can trace the trialectic processes of reproduction of human capital. This is due to three key points:

- the production process is based on the threefold interaction and reproduction of three key origins: material, informational, synergistic; 
- the process of consumption provides a reproduction of the triune nature of man, which carries biological, social (personal), and labor (economic) origins;

- production and consumer transaction can be considered a kind of triad, in which the sphere of production (also being a triad) is mainly of material and energy origin (producing goods), the sphere of consumption provides mainly informational origin (giving impulse to production in the form of answers to questions: what, how much, how and for whom to produce?), and the interface sphere (marketing, trade) - a synergetic origin (connecting these two areas).

Today, when humanity has entered a phase of the transition to a new socio-economic formation, the role of human capital has grown significantly. It is becoming increasingly clear that the success of economic systems is determined not by tangible assets (natural resources, means of production, financial funds), but by the quality of human capital. The issues of filling the content of human capital transformations, which are dictated by the course of modern industrial revolutions (Industries 3.0; 4.0 5.0), which define the contours of the future digital economy, are becoming more and more relevant.

\section{References}

1. Smit, A. (1993). Issledovanie o prirode i prichinah bogatstva narodov. Antologiya ekonomicheskoy myisli [Research on the nature and causes of the wealth of nations. Anthology of Economic Thought]. MP "EKONOV", "KLYUCH". [in Russian].

2. Marks, K. (1983). Kapital. Kritika politicheskoy ekonomii [Capital. Criticism of Political Economy] (Vol. 1). Politizdat. [in Russian].

3. Marshall, A. (1993). Printsipyi ekonomicheskoy nauki [Principles of economic science]. Eksmo. [in Russian].

4. Say, J.- B. \& Bastiat, F. (2000). Traktat po politicheskoy ekonomii [Treatise on Political Economy] Case. [in Russian].

5. Clark, J. B. (2000). Raspredelenie bogatstva [The Distribution of Wealth]. Gelios ARV. [in Russian].

6. Schumpeter, J. (2011) Teoriia ekonomichnoho rozvytku [The theory of economic development]. KyivMohyla Academy. [in Ukrainian].

7. Becker, G. S. (1994). Human capital: a theoretical and empirical analisys with special reference to education. National Bureau of Economic Research.

8. Schultz, T. W. (1961). Investment in human capital. The American Economic Review, 51(1), 1-17.

9. Mincer, J. (Aug., 1958). Investment in human capital and personal income distribution. Journal of Political Economy, 66(4), 281-302.

10. Thurow, L. C. (1970). Investment in Human Capital. Wadsworth Series in Labor Economics and Industrial Relations. Wadsworth Publishing Company.

11. Melnyk, L., Derykolenko, O., Kubatko, O. \& Matsenko, O. (2019, June). Business Models of Reproduction Cycles for Digital Economy. ICT in Education, Research and Industrial Applications. Integration, Harmonization and Knowledge Transfer. (Vol. 2). CEUR-WS. Retrieved from https://essuir.sumdu.edu.ua/handle/123456789/74617

12. Tarkhov, P. V., Matsenko, A. M., Krugliak, A. P. \& Derkach, Z. V. (2012). Provision of integrity and reliability in hygienic examination of investment projects for human capital development. Gigiena $i$ sanitariya - Hygiene and sanitation, 5, 91-94. Retrieved from https://essuir.sumdu.edu.ua/handle/123456789/74619 [in Russian].

13. Matsenko, A. M., Safiulin, A. A., Tarkhov, P. V., Derkach, Zh. V. (2012). Konkurentosposobnost chelovecheskogo kapitala kak kriteriy ekspertizyi investitsionnyih proektov [The competitiveness of human capital as a criterion for the examination of investment projects]. Problemy i perspektyvy rozvytku bankivskoi systemy Ukrainy - Problems and prospects for the development of the banking system of Ukraine, Vol.36, 97-107. Retrieved from https://essuir.sumdu.edu.ua/handle/123456789/58633 [in Russian]. 
14. Tarkhov, P. V., Matsenko, O. M. \& Derkach, J. V. (2011). Ekonomiko-envaironmentalnoe blahopoluchchia yak osnova konkurentospromozhnosti liudskoho kapitalu [Economic and environmental well-being as the basis for the competitiveness of human capital]. Ekonomichnyi prostir - Economic space, 56/2, 282-292 [in Russian].

15. Tarkhov, P. V. (2013). Suchasna model zabezpechennia konkurentospromozhnosti liudskoho kapitalu. Suspilstvo i ekonomika postradianskoho prostoru. The modern model of ensuring the competitiveness of human capital. Society and economy of the post-Soviet space - Society and economy of the postSoviet space, Vol. 2, 163-173. Retrieved from https://essuir.sumdu.edu.ua/handle/123456789/80589 [in Russian].

16. Melnyk, L., Matsenko, O., Dehtyarova, I. \& Derykolenko, O. (2019). The formation of the digital society: social and humanitarian aspects. Digital economy and digital society. T. Nestorenko \& M. Wierzbik-Strońska (Ed.). Katowice: Katowice School of Technology. Retrieved from http://essuir.sumdu.edu.ua/handle/123456789/74570

17. Melnyk, L. Hr., Matsenko, O. M. \& Zavdov'eva, Yu. M. (2019). Konkurentni Preymushchestva mashinobudivnikh pidpryiemstv v uslovyiakh tsyfrovoi transformatsii [Competitive rides of machineand-food enterprises in the minds of digital transformation]. Suchasnyi menedzhment ekonomichnykh system $v$ koordynatakh paradyhmy staloho rozvytku - Modern management of economic systems in the coordinates of paradigms of steel development (pp. 43-47). ONP. Retrieved from https://essuir.sumdu.edu.ua/handle/123456789/75236 [in Ukrainian].

18. Melnyk, L. Hr., Matsenko, O. M. \& Kirilenko, M. V. (2019). Kreatyvnyi liudskyi kapital yak faktor formyrovanye vyrobnychoho potentsialu. [Creative human capital is a factor in the formulation of viral potential]. Ekonomichnyi rozvytok derzhavy ta ee sotsialna stabilnist - Economic development of the state and social stability (pp. 110-112). IE Pusan, A. F. Retrieved from http://essuir.sumdu.edu.ua/handle/123456789/74567 [in Ukrainian].

19. Matsenko O., Kopilova N., Tkachenko O. \& Solodova Ye. (2018). Vplyv ekonomichnoho dobrobutu na mihratsiiu liudskoho Kapitalu [Injection of an economical well-being to the migration of human capital]. STABICONsystems (pp. 74-76). Sumy State University [in Ukrainian].

20. Vechkanov, H. S. \& Vechkanov, H. R. (2002). Sovremennaya ekonomicheskaya entsiklopediya [Modern economic encyclopedia]. Lan. [in Russian].

21. Rayzberg, B. A., Lozovskiy, L. Sh. \& Starodubtseva, E. B. (2010). Sovremennyiy ekonomicheskiy slovar [Modern economic dictionary]. INFRA-M. [in Russian]

22. Ekonomicheskaya entsiklopediya [Economic encyclopedia] (L. I. Abalkin, Ch. ed.). (1999). Economy. [in Russian].

23. Slovar sovremennoy ekonomicheskoy teorii Makmillana [Macmillan's Dictionary of Modern Economics]. (2003). INFRA-M. [in Russian].

24. Populyarnaya ekonomicheskaya entsiklopediya [Popular economic encyclopedia] (A. D. Nekipelov, Ch. Ed.). (2001). Great Russian Encyclopedia. [in Russian].

25. Melnyk, L. Hr. (2018). "Mashina vremeni” N. N. Neplyueva (Sotsialno-ekonomicheskiy analiz) [N. N Nepliuev`s "Time Machine" (Socio-economic analysis)]. University book. [in Russian].

26. Boulding, K. E. (1966). The economics of the coming Spaceship Earth. (N. Nelisse, J. Van Den Straaten \& L. Klinkers, Eds.). Resources for the Future.

27. Agamirzyan I. (2013). Tretya promyishlennaya revolyutsiya : nachalo [The third industrial revolution: the beginning]. Retrieved from https://www.rvc.ru/press-service/media-review/rvk/39731/ [in Russian].

28. Rifkin, J. (2013). The Third Industrial Revolution: How Lateral Power is Transforming Energy, The Economy, and The World. St. Martin's Griffin Publisher.

29. Rifkin, J. (2015). Zero Marginal Cost Society: The Internet of Things, the Collaborative Commons, and the Eclipse of Capitalism. St. Martin's Griffin Publisher.

30. Schwab, K. \& Davis, N. (2018) Shaping the Fourth Industrial Revolution. Would economic Forum, Committed to Improving the State of the World.

31. Schwab, K. (2017). The Fourth Industrial Revolution. World Economic Forum, Committed to Improving the State of the World. 
Л. Г. Мельник, О. М. Маценко, В. С. Півень, О. М. Дериколенко,

М. В. Кириленко. Формування людського капіталу в цифровій економіці

32. Rossi, B. What will Industry 5.0 mean for manufacturing? Raconteur. Retrieved from https://www.raconteur.net/technology/manufacturing-gets-personal-industry-5-0

Manuscript received 30 October 2020

Формирование человеческого капитала в цифровой экономике

\author{
ЛЕОНИД ГРИГОРЬЕВИЧ МЕЛЬНИК, \\ АЛЕКСАНДР МИХАЙЛОВИЧ МАЦЕНКО \\ ВЛАДИСЛАВ СЕРГЕЕВИЧ ПИВЕНЬ ${ }^{* * *}$, \\ АЛЕКСАНДР НИКОЛАЕВИЧ ДЕРИКОЛЕНКО ${ }^{* * * *}$, \\ МАКСИМ ВИКТОРОВИЧ КИРИЛЕНКО
}

* доктор экономических наук, профессор, профессор кафедры экономики, предпринимательства и бизнес-администрирования Сумского государственного университета, директор Научно-исследовательского института экономики развития МОН Украины и НАН

Украины в составе Сумского государственного университета, ул. Р.-Корсакова, 2, г. Сумы, 40007, Украина,

тел.: 00-380-542-332223, e-mail: melnyk@econ.sumdu.edu.ua

** кандидат экономических наук, доиент, доцент кафедры экономики, предпринимательства и бизнес-администрирования Сумского государственного университета, ул. Р.-Корсакова, 2, г. Сумы, 40007, Украина,

тел.: 00-380-542-332223,e-mail: amatsenko@econ.sumdu.edu.ua

*** студент Учебно-научного института финансов, экономики и менеджмента имени Олега Балацккого Сумского государственного университета, ул. Р.-Корсакова, 2, г. Сумы, 40007, Украина,

тел.: 00-380-542-332223, e-mail:vladislavpiven2002@gmail.com

**** доктор экономических наук, дочент кафедры экономики, предпринимательства и бизнес-администрирования Сумского государственного университета, ул. Р.-Корсакова, 2, г. Сумьл, 40007, Украина, тел.:00-380-542-332223,e-mail: o.derykolenko@econ.sumdu.edu.ua

***** студент Учебно-научного института финансов, экономики и менеджсмента имени Олега Балацкого Сумского государственного университета, ул. Р.-Корсакова, 2, г. Сумь, 40007, Украина,

тел.: 00-380-661-854673; e-mail: kirilenkom274@gmail.com

В статье исследуются роль и различные проявления человеческого капитала в функционировании и развитии цифровой экономики. Ключевым контекстом исследования является феномен воспроизводства компонентов человеческого капитала, включая процессы производства и потребления. В качестве важной предпосылки воспроизводства анализируется феномен упорядочения трех основных начал функционирования экономических систем: материального, информационного и синергетического. Взаимосвязь и взаимодействие этих источников играют важную роль в формировании различных типов капитала, включая человеческий. В статье раскрываются содержание и направления инвестирования в основные составляющие воспроизводственного цикла экономической системы: спрос, отношения собственности, исполнители, органы управления, инфраструктура, природные факторы. Статья посвящена анализу триалектических основ воспроизводства человеческого капитала через формирование и взаимодействие сущностных начал человека: биологического, социального и 
Leonid Hr. Melnyk, Oleksandr M. Matsenko, Vladyslav S. Piven,

Oleksandr M. Derykolenko, Maksym V. Kyrylenko. Formation of Human Capital in the Digital Economy

трудового. Человек-потребитель в цифровой экономике принципиально отличается от человекапотребителя предыдущих эпох. Главное, чтобы подавляющее большинство личных потребностей становились самоцелью, а не средством получения материальной выгоды в будущем. Человекпроизводитель будет все больше переходить от воздействия на материальные объекты труда (изменение формы, размеров, свойств) к воздействию на информацию (развитие творческих индустрий, выбор полезной информации из больших массивов данных). На основе анализа содержательной основы трех промышленных революций (третьей, четвертой и пятой) прогнозируются трансформационные изменения, которые должны произойти на этапе перехода к новой социально-экономической формации. Основные из них - сестейнизация человеческого сознания, цифровизация и сетивизация компетенций; формирование умения жить в условиях Интернета вещей; социологизация развития и др.

Ключевые слова: человеческий капитал, экономическая система, процесс, цифровая экономика, промышленная революция.

\author{
Mechanism of Economic Regulation, 2020, No 4, 19-35 \\ ISSN 1726-8699 (print)
}

\title{
Формування людського капіталу в цифровій економіці
}

\author{
ЛЕОНІД ГРИГОРОВИч МЕЛЬНИК, \\ ОЛЕКСАНДР МИХАЙЛОВИЧ МАЦЕНКО**, \\ ВЛАДИСЛАВ СЕРГІйОВИч ПІвЕнь \\ ОЛЕКСАНДР МИКОЛАйОВич ДЕРИКОЛЕНКо ${ }^{* * * *}$, \\ МАКСИМ ВІкторович КИРИЛЕнКо ${ }^{* * * * *}$
}

\footnotetext{
* доктор економічних наук, професор, професор кафедри економіки, підприємництва та бізнесадміністрування Сумського державного університету, директор Науково-дослідного інституту економіки розвитку МОН України і НАН Украӥни у складі

Сумського державного університету

вул. Р.-Корсакова, 2, м. Суми, 40007, Украӥна,

тел.: 00-380-542-332223, e-mail: melnyk@econ.sumdu.edu.ua

** кандидат економічних наук, доцент, дочент кафедри економіки, підприємництва та бізнес-адміністрування Сумського державного університету, вул. Р.-Корсакова, 2, м. Суми, 40007, Украӥна, тел.: 00-380-542-332223, e-mail: amatsenko@econ.sumdu.edu.ua

*** студент Навчально-наукового інституту фінансів, економіки та менеджменту імені Олега Балачького Сумського державного університету вул. Р.-Корсакова, 2, м. Суми, 40007, Украӥна, тел.: 00-380-542-332223, e-mail: vladislavpiven2002@gmail.com

**** доктор економічних наук, доцент кафедри економіки, підприємництва та бізнес-адміністрування Сумського державного університету вул. Р.-Корсакова, 2, м. Суми, 40007, Украӥна,

тел.: 00-380-542-332223, e-mail: o.derykolenko@econ.sumdu.edu.ua

****** студент Навчально-наукового інституту фінансів, економіки та менеджменту імені Олега Балацького Сумського державного університету вул. Р.-Корсакова, 2, м. Суми, 40007, Украӥна, тел.: 00-380-661-854673; e-mail: kirilenkom274@gmail.com
} 
У статті досліджено роль та різні прояви людського капіталу у функціонуванні та розвитку цифрової економіки. Ключовим контекстом дослідження $є$ явище відтворення складових людського капіталу, включаючи процеси виробництва та споживання. Як важлива передумова відтворення аналізується явище впорядкування трьох основних витоків функціонування економічних систем: матеріального, інформаційного та синергетичного. Взаємозв'язок та взаємодія цих витоків відіграють важливу роль у формуванні різних видів капіталу, зокрема людського. У статті розкрито зміст та напрями інвестування в основні компоненти відтворювального циклу економічної системи: попит, відносини власності, виконавці, органи управління, інфраструктура та природні фактори. Зосереджено увагу на аналізі триалектичних основ відтворення людського капіталу через формування та взаємодію основних витоків людини: біологічного, соціального та трудового. Людина-споживач цифрової економіки принципово відрізняється від споживача людини попередніх епох. Головне, що переважна більшість особистих потреб стає самоціллю, а не засобом отримання матеріальних благ у майбутньому. Людина-виробник все частіше переходитиме від впливу на матеріальні предмети праці (зміна форм, розмірів, властивостей) до впливу на інформацію (розвиток креативних індустрій, вибір корисної інформації з великих масивів даних). На основі аналізу предметної основи трьох промислових революцій (третьої, четвертої та п’ятої) прогнозуються трансформаційні зміни, які мають відбутися на етапі переходу до нової соціально-економічної формації. Основні з них - це підтримка людської свідомості, цифровізація та мережева компетенція; формування здатності жити в умовах Інтернету речей; соціологізація розвитку тощо.

Ключові слова: людський капітал, економічна система, процес, цифрова економіка, промислова революція.

JEL Codes: O15, J24, E24

Table: 1; Figure: 2; References: 32

Language of the article: English

Лimepamypa

1. Смит, А. Исследование о природе и причинах богатства народов. Антология экономической мысли. Москва : МП «ЭКОНОВ», «КЛЮЧ», 1993. С. 79-396 с.

2. Маркс, К. Капитал. Критика политической экономии. Москва : «Политиздат», 1983. Т. 1. 737 с.

3. Маршалл, А. Принципы экономической науки. Москва : «Эксмо», 1993. 832 с.

4. Сэй, Ж. - Б., Бастиа Ф. Трактат по политической экономии. Москва : Дело, 2000. С. 22-88.

5. Кларк, Дж. Б. Распределение богатства. Москва : «Гелиос АРВ», 2000. 368 с.

6. Шумпетер, Й. Теорія економічного розвитку. Київ : Києво-Могилянська академія, 2011. 244 с.

7. Becker, G. S. Human capital: a theoretical and empirical analisys with special reference to education. New York : National Burean of Econonic Research, 1994. 187 p.

8. Schultz, T. W. Investment in human capital. The American Economic Review. 1961. Vol. 51. No. 1. P. 1-17.

9. Mincer, $J$. Investment in human capital and personal income distribution. Journal of Political Economy. 1958. Vol. 66, No. 4. P. 281-302.

10. Thurow, L. C. Investment in Human Capital. Belmont : Wadsworth Publishing Company, 1970. 145 p.

11. Melnyk, L., Derykolenko, O., Kubatko, O., Matsenko, O. Business Models of Reproduction Cycles for Digital Economy. Proceedings of the 15th International Conference on ICT in Education, Research and Industrial Applications. Integration, Harmonization and Knowledge Transfer. Kherson : CEURWS, 2019. Vol. 2. URL : https://essuir.sumdu.edu.ua/handle/123456789/74617

12. Тархов П. В., Маценко А.М., Кругляк А.П., Деркач Ж.В. Обеспечение полноты и надёжности гигиенической экспертизы инвестиционных проектов для развития человеческого капитала. Гигиена $u$ санитария. 2012. № 5. C. 91-94. URL : https://essuir.sumdu.edu.ua/handle/123456789/74619

13. Конкурентоспособность человеческого капитала как критерий экспертизы инвестиционных проектов / А. М. Маценко, А. А. Сафиулин, П. В. Тархов, Ж. В. Деркач. Проблемы $и$ 
Leonid Hr. Melnyk, Oleksandr M. Matsenko, Vladyslav S. Piven,

Oleksandr M. Derykolenko, Maksym V. Kyrylenko. Formation of Human Capital in the Digital Economy

перспективы развития банковской системы Украины: сборник научных трудов. 2012. Вып. 36. C. 97-107. URL : https://essuir.sumdu.edu.ua/handle/123456789/58633

14. Тархов, П. В., Маценко, А. М. Деркач, Ж. В. Экономико-энвайронментальное благополучие как основа конкурентоспособности человеческого капитала. Экономическое пространство : сборник научных трудов. 2011. № 56/2. С. 282-292.

15. Современная модель обеспечения конкурентоспособности человеческого капитала / П. В. Тархов и др. Общество и экономика постсоветского пространства. 2013. Выпуск 2. C. 163-173. URL: https://essuir.sumdu.edu.ua/handle/123456789/80589

16. Melnyk, L., Matsenko, O., Dehtyarova, I., Derykolenko, O. The formation of the digital society: social and humanitarian aspects. Digital economy and digital society / ed. by T. Nestorenko \& M. WierzbikStrońska. Katowice: Katowice School of Technology, 2019. URL: http://essuir.sumdu.edu.ua/handle/123456789/74570

17. Мельник, Л. Г., Маценко, О. М., Завдов’єва, Ю. М. Конкурентні переваги машинобудівних підприємств в умовах цифрової трансформації. Сучасний менеджмент економічних систем 6 координатах парадигми сталого розвитку : матеріали I Міжнародної науково-практичної конференції, 18 вересня 2019 р. Одеса: ОНПУ, 2019. С. 43-47. URL : https://essuir.sumdu.edu.ua/handle/123456789/75236

18. Мельник, Л. Г., Маценко, О. М., Кириленко, М. В. Креативний людський капітал як фактор формування виробничого потенціалу. Економічний розвиток держави та іiі соціальна стабільність: матеріали III Міжнародної науково-практичної конференції, 15 травня 2019 р.
Полтава :
ФОП
Пусан А. Ф.
2019.
C.
$110-112$
URL :

http://essuir.sumdu.edu.ua/handle/123456789/74567

19. Маценко, O., Копилова, Н., Ткаченко, О., Солодова, Є. Вплив економічного добробуту на міграцію людського капіталу. STABICONsystems: матеріали Міжнародного наукового форуму, 26-28 квітня 2018 р. Суми : Сумський державний університет, 2018. С. 74-76.

20. Вечканов, Г. С., Вечканова, Г. Р. Современная экономическая $\quad$ энциклопедия. СанктПетербург : «Лань», 2002.880 с.

21. Райзберг, Б. А., Лозовский, Л. Ш., Стародубцева, Е. Б. Современный экономический словарь. Москва : ИНФРА-М, 2010. 12 с.

22. Экономическая энциклопедия / гл. ред. Л. И. Абалкин. Москва : Экономика, 1999. 1055 с.

23. Словарь современной экономической теории Макмиллана; пер. с англ. Д. У. Пирса. Москва : ИНФРА-М., 2003. 608 с.

24. Популярная экономическая энциклопедия / гл. ред. А. Д. Некипелов. Москва : Большая Российская энциклопедия, 2001. 367 с.

25. Мельник, Л. Г. «Машина времени» Н. Н. Неплюева (Социально-экономический анализ) монография. Сумы : Университетская книга, 2018. 368 с.

26. Boulding, K. E. The economics of the coming Spaceship Earth. Classics in environmental studies. An overview of classic texts in environmental studies / ed. by N. Nelisse, J. Van Den Straaten and L. Klinkers. Amsterdam, the Netherland, 1966. P. 218-228.

27. Агамирзян, И. Третья промышленная революция : начало. PBK. URL : https://www.rvc.ru/pressservice/media-review/rvk/39731/

28. Rifkin, J. The Third Industrial Revolution: How Lateral Power is Transforming Energy, The Economy, and The World. New York : St. Martin's Griffin Publisher, 2013. 304 p.

29. Rifkin, J. Zero Marginal Cost Society: The Internet of Things, the Collaborative Commons, and the Eclipse of Capitalism. New York : St. Martin's Griffin Publisher, 2015. 448 p.

30. Schwab, K., Davis, N. Shaping the Fourth Industrial Revolution. Cologny, Switzerland : Would economic Forum, Committed to Improving the State of the World, 2018. $320 \mathrm{p}$

31. Schwab, K. The Fourth Industrial Revolution. World Economic Forum, Committed to Improving the State of the World, 2017. $208 \mathrm{p}$.

32. Rossi, B. What will Industry 5.0 mean for manufacturing? Raconteur. URL : https://www.raconteur.net/technology/manufacturing-gets-personal-industry-5-0 